\title{
Human T lymphotropic virus type 1 (HTLV-1) proviral load induces activation of T-lymphocytes in asymptomatic carriers
}

\author{
Raimundo Coutinho $\mathrm{Jr}^{1}$, Maria Fernanda Rios Grassi ${ }^{1,2^{*}}$, Ana Beatriz Korngold ${ }^{1}$, Viviana Nilla Olavarria², \\ Bernardo Galvão-Castro ${ }^{1,2}$ and Rita Elizabeth Mascarenhas ${ }^{1,2}$
}

\begin{abstract}
Background: High HTLV-1 proviral load (PVL) is mainly found in infected individuals with HTLV-1-associated myelopathy/tropical spastic paraparesis (HAM/TSP). However one third of asymptomatic carriers may have high PVL. This study aimed to evaluate the impact of PVL in the activation of T lymphocytes of asymptomatic individuals infected with HTLV-1.

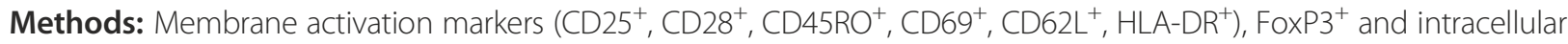
IFN- $\gamma$ expression were evaluated on both $\mathrm{CD}^{+}$and $\mathrm{CD} 8+$ T-lymphocytes from asymptomatic carriers with $\mathrm{PVL} \geq$ and $<1 \%$ of infected cells, using flow cytometry. HTLV-1 proviral load was determined using real-time PCR.

Results: Asymptomatic carriers with $P V L \geq 1 \%$ presented a higher frequency of $C D 4^{+} C D 25^{+} C D 45 R O^{+}(13.2 \%$ vs. $4 \%$, $p=0.02), C D 4^{+} H L A-D R^{+}(18 \%$ vs. $8.3 \%, p=0.01)$ and $C D 4^{+} I F N-\gamma^{+}(4.5 \% ; 1 \%, p=0.01)$ T-cells, than healthy donors. HTLV-1 PVL was directly correlated with the proportion of $C D 4^{+} C D 25^{+} C D 45 R O^{+} T$-cells $(R=0.7, p=0.003)$. Moreover, a significant increase in the proportion of CD4 + FoxP3+ T-cells was observed in HTLV-1-infected individuals, compared to healthy donors.

Conclusion: HTLV-1 PVL is associated with activation of both $C D 4^{+}$and $C D 8^{+}$T-lymphocytes in asymptomatic individuals. Prospective studies should be conducted to evaluate whether asymptomatic individuals with higher PVL and high immune activation are more prone to developing HTLV-1-associated diseases.
\end{abstract}

Keywords: HTLV-1, Proviral load, Asymptomatic, Activation

\section{Background}

The human T-lymphotropic virus type 1 (HTLV-1) was the first retrovirus known to cause disease in humans, initially isolated from the lymphocytes of a patient with cutaneous T-cell lymphoma in 1980 [1]. An estimated 10 to 20 million individuals are currently infected with HTLV-1 worldwide, mostly clustered in Japan, the Caribbean, Africa, and Latin America, with Brazil having the highest number of infected individuals [2]. This virus is recognized as the etiologic agent of HTLV-Associated Myelopathy/Tropical Spastic Paraparesis (HAM/TSP) [3,4] and adult T-cell

\footnotetext{
* Correspondence: grassi@bahia.fiocruz.br

'Advanced Laboratory of Public Health/CPQGM - Oswaldo Cruz Foundation (FIOCRUZ), Rua Waldemar Falcão, no 121, Candeal, Salvador, Bahia CEP 40296-710, Brazil

${ }^{2}$ Bahiana School of Medicine and Public Health, Salvador, Bahia, Brazil
}

leukemia/lymphoma (ATL) [5], which affect less than $5 \%$ of all infected individuals, and occasionally causes HTLV-associated uveitis (HAU) [6] and infective dermatitis in children [7]. Other infectious diseases, such as strongyloidiasis [8] and tuberculosis $[9,10]$, have also been described at a higher prevalence in patients infected with HTLV-1.

The association with these infectious diseases suggests that HTLV-1 may impair the host immune response, possibly leading to immunosuppression. Similar to the human immunodeficiency virus (HIV), HTLV-1 also integrates its genome into host cells, thereby establishing a persistent chronic infection. While HIV induces a potent immunodepression by destroying CD4+ T-cells, HTLV-1 promotes the spontaneous proliferation of CD4+ and CD8 + T-cell subsets, as well as NK cells [11-13]. 
HTLV-1-infected individuals frequently present immunological abnormalities, such as increased inflammatory cytokine production and T-lymphocyte activation, as well as a reduced lymphoproliferative response to recall antigens in vitro [13,14]. Moreover, immune system activation occurs more frequently and with greater intensity in individuals with HAM/TSP [14,15]. These individuals often present alterations in regulatory T-cells $[16,17]$.

In the HIV infection, the plasmatic viral load is positively correlated with the intensity of T-cell activation, as well as the destruction of $\mathrm{CD}^{+}$T-lymphocytes and a progression to AIDS [18]. The general immune activation and exhaustion of immune system caused by HIV play also an important role in the immunodepression observed in AIDS patients [19]. By contrast, HTLV-1 proviral load (PVL) is not widely recognized as a biomarker to predict HTLV-associated disease evolution. HTLV-1 PVL is considered low if the proportion of infected PBMCs is lower than $1 \%$, and high if greater than 5\% [20]. High PVLs are commonly found in individuals with HAM/TSP [21,22], infective dermatitis [23] and Keratoconjunctivitis sicca [24]. However, in some cases, asymptomatic individuals may have high PVLs and exhibit an exacerbated inflammatory response [14,22]. To investigate the association between PVL and immune system activation, the present study evaluated the phenotypic profile of $\mathrm{CD} 4^{+}$and $\mathrm{CD} 8^{+}$T-cells in asymptomatic individuals infected with HTLV-1.

\section{Methods}

\section{Subjects}

Fifty seven asymptomatic HTLV-1-infected subjects were sequentially selected from the Bahiana School of Medicine and Public Health HTLV reference center (Salvador, Bahia, Brazil). They were included if evaluated neurologic examination was normal and had no clinical complaints. Exclusion criteria were co-infection with HIV and/or $\mathrm{HCV}$, as well as other HTLV-1-associated diseases, such as infective dermatitis, uveitis, ATL. Eleven laboratory staff volunteered as non-infected controls. All samples were screened for HTLV-1/2 antibodies by an enzyme-linked immunosorbent assay (ELISA) (Ab-Capture ELISA Test System - Ortho-Clinical Diagnostics, Inc., Raritan, New Jersey), and positive results were confirmed by Western Blot (HTLV Blot 2.4, Genelabs Technologies, Singapore). The number of evaluated in the immunological assays was as follow: spontaneous proliferation $\mathrm{n}=28$ HTLV-1infected individuals, activation markers on $\mathrm{CD} 4$ and $\mathrm{CD} 8^{+}$ T-subsets $\mathrm{n}=10$ and $\mathrm{CD}^{+} \mathrm{FoxP}^{+} \mathrm{n}=15$ HTLV-1infected individuals and 5 uninfected controls). This study was approved by the Ethical Committee of the Oswaldo Cruz Foundation (FIOCRUZ). Informed written consent was obtained from all enrolled individuals and the FIOCRUZ Institutional Review Board approved this study.

\section{Proliferation assay}

Blood samples were collected from all study subjects in heparin tubes and peripheral blood mononuclear cells (PBMC) were isolated using a Ficoll-Paque Plus density gradient centrifuge (GE Healthcare Bio-Sciences $A B$, Uppsala, Sweden). Cultures of $10^{5}$ PBMCs were incubated in triplicate for five days $\left(37^{\circ} \mathrm{C}, 5 \% \mathrm{CO}_{2}\right)$ in RPMI- 1640 medium (Sigma Chemical Co., St. Louis, MO, USA) supplemented with $2 \mathrm{mM}$ L-glutamine, $1 \mathrm{mM}$ nonessential amino acids, $1 \mathrm{mM}$ sodium pyruvate, $100 \mathrm{U} / \mathrm{ml}$ penicillin, $100 \mathrm{~g} / \mathrm{ml}$ streptomycin and pooled human $A B$ serum (10\%) (Sigma). On the last day of incubation, cells were pulsed overnight with $1 \mu \mathrm{Ci}[3 \mathrm{H}]$ thymidine (specific activity, $2 \mathrm{Ci} / \mathrm{mmol}$; ICN, Costa Mesa, CA). Incorporated [3H] thymidine was measured in terms of mean counts per minute (CPM) using $\beta$-radiation counter (MATRIX 9600 direct beta counter; Packard). Spontaneous proliferation of PBMCs was considered when a mean CPM value $\geq 500$ due in triplicates (i.e., three times the mean counts per minute measured in uninfected control cells) was obtained.

\section{Flow cytometry}

$50 \mu \mathrm{l}$ of whole blood was incubated for $15 \mathrm{~min}$ at room temperature with anti-CD4 (BD Pharmingen Technical) and the following monoclonal antibodies: CD45RO, CD25, CD69, CD62L, CD28, and HLA-DR (Immunothec, a Beckman Coulter Company). Erythrocytes were subsequently lysed with FACS ${ }^{\mathrm{ma}}$ lysing solution (BectonDickinson Immunocytometry System, San Jose, CA, USA). After a final wash, the cells were fixed in PBS containing $1 \%$ paraformaldehyde. Alternatively, for detection of intracellular FoxP3, $80 \mu \mathrm{l}$ of whole blood was incubated for $15 \mathrm{~min}$ at room temperature with antiCD3 and CD4 monoclonal antibodies (Becton Dickinson, Mountain View, Calif.), after 15 min the cells were washed twice with PBS-BSA-Saponin $0.2 \%$ and blocked with AB serum $1 \%$ for $5 \mathrm{~min}$. After that, the cells were incubated with anti-FoxP3 for $30 \mathrm{~min}$. The cells were washed and fixed. Analyses were performed using FACSaria II (Becton Dickinson, Mountain View, Calif.) and the software FlowJo 7.5 (Tree stars, San Diego). At least $10^{5}$ events were analyzed per sample.

\section{Detection of intracellular IFN- $\gamma$}

PBMCs $\left(2 \times 10^{5}\right.$ cells/well) were cultured in RPMI 1640 (Sigma Chemical Co., St. Louis, MO) medium, supplemented with $25 \mathrm{mM}$ of HEPES, $2 \mathrm{mM}$ of L-glutamine, $1 \mathrm{mM}$ nonessential amino acids, $1 \mathrm{mM}$ sodium pyruvate, $100 \mathrm{U} / \mathrm{mL}$ of penicillin, $100 \mathrm{~g} / \mathrm{mL}$ of streptomycin and 
$10 \%$ pooled human $A B$ serum (Sigma), and plated in triplicate in 96-well U-bottom plates (Costar, Cambridge, $\mathrm{MA})$, then incubated for $4 \mathrm{~h}$ at $37^{\circ} \mathrm{C}$ under $5 \% \mathrm{CO}_{2}$. Next, monensin and brefeldin $(3 \mu \mathrm{g} / \mathrm{ml})$ in $\mathrm{AB}$ serum (10\%) (Sigma) were added to each culture, and then reincubated for $16 \mathrm{~h}$. The cells were then washed with PBS-BSA-PFA-azide $(2 \mathrm{~mL})$ and stained with monoclonal anti-CD4, and antiCD3 antibodies for $15 \mathrm{~min}$ at $4^{\circ} \mathrm{C}$. The cells were then fixed in PBS containing 4\% paraformaldehyde $200 \mu \mathrm{l}$ for $20 \mathrm{~min}$ at room temperature, followed by two washing cycles with 0.1\% PBS-BSASaponin. Positive control cells were cultured with $2 \mu \mathrm{g} / \mathrm{ml}$ phytohaemagglutinin (PHA) (Sigma). To conduct intracellular cytokine staining, the cells were then reincubated for 30 min with anti-IFN- $\gamma$-PE monoclonal antibodies or isotype controls, then washed with 0.1\% PBS-BSA-Saponin, and washed again with PBS-BSA-PFA-azide. Cells were analyzed using a FACSort flow cytometer and data was interpreted by Cellquest software (Becton Dickinson, Mountain View, Calif.).

\section{Proviral load}

PBMCs were obtained from EDTA blood using density gradient centrifugation and cryopreserved until use. DNA was extracted using a DNA extraction system (Qiagen, Hilden, Germany). HTLV-1 proviral load was quantified using a real-time TaqMan polymerase chain reaction (PCR) method, as previously described [25]. Briefly, SK110/SK111 primers were used to amplify a $186 \mathrm{bp}$ fragment of the pol gene and dual TaqMan probe (50-FAM/ 50 VIC and 30-TAMRA) was attached at 4,829-4,858 bp of the HTLV- 1 reference sequence (HTLVATK). Albumin DNA was used as an endogenous reference and HTLV-1 PVL was calculated as the ratio of [(HTLV-1 DNA average copy number)/(albumin DNA average copy number)] $\times$ $2 \times 10^{6}$ and expressed as the number of HTLV-1 copies per $10^{6}$ PBMCs.

\section{Statistical analyses}

Data are expressed as median and interquartile range (25th percentile and the 75th percentile). Kruskal-Wallis
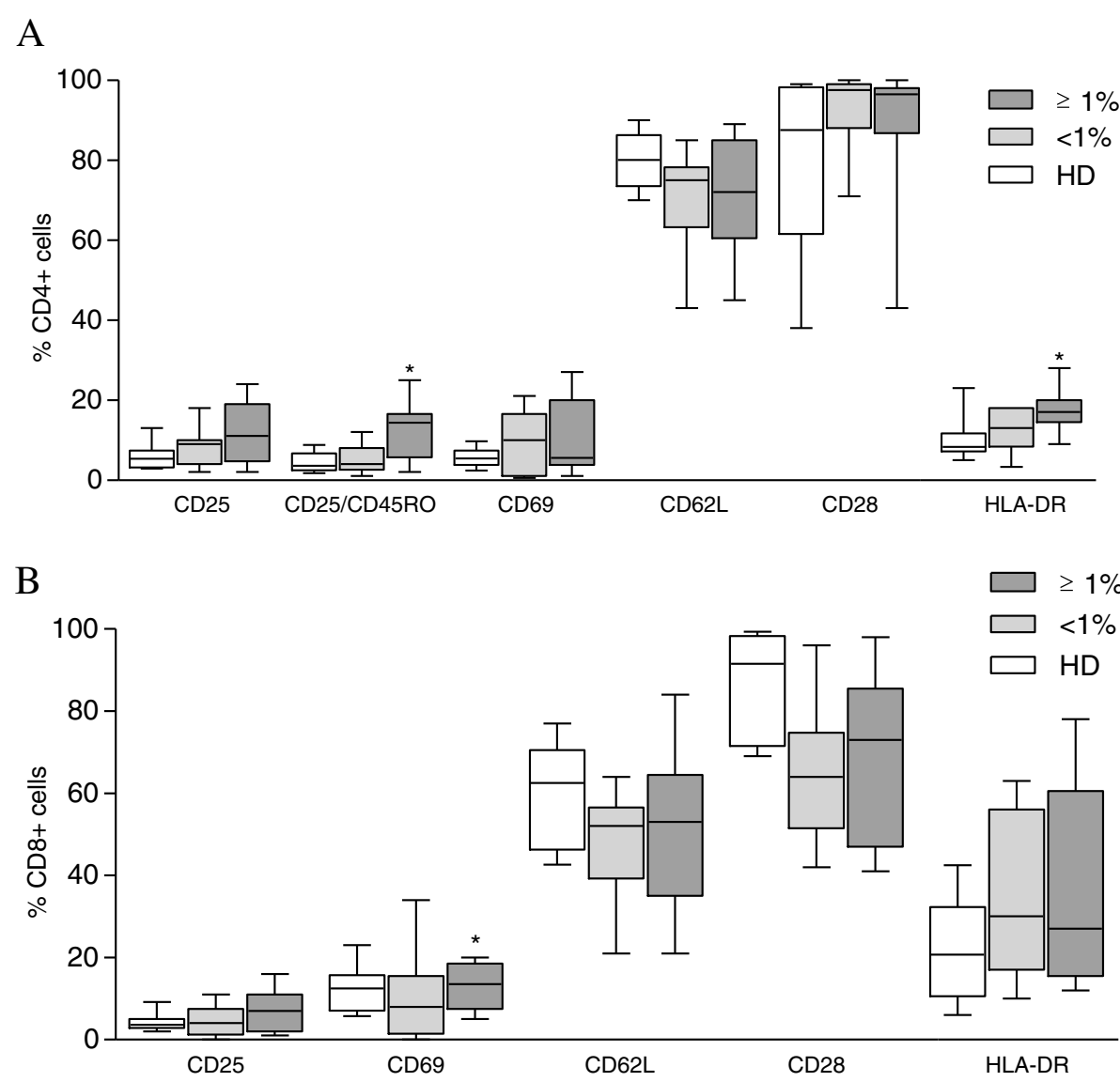

Figure 1 Activation profile of CD4+ (A) and CD8+ (B) T-lymphocytes from asymptomatic HTLV-1-infected individuals. Flow cytometry was performed using fresh whole blood samples. Data represents median and interquartile range of 20 asymptomatic HTLV-1infected individuals grouped according to HTLV-1 PVL expressed as $\geq 1 \%$ (10 individuals) and $<1 \%$ of infected cells (10 individuals) and 10 healthy donors (HD). Kruskal-Wallis test with the Bonferroni-Dunn multiple comparisons. The level of significance was set at $P<0.05$. 
non-parametric analysis of variance with the BonferroniDunn multiple comparison tests was used to compare healthy donors, asymptomatic with $\mathrm{PVL} \geq 1 \%$ and $<1 \%$ of infected cells groups. The Fisher exact chi-square test was used to compare lymphoproliferation frequencies. The correlations were performed by Spearman correlation test. Significant differences were considered for $\mathrm{p}<0.05$. GraphPad Prism 5 (La Jolla, CA) Software was used for all statistical analyses.

\section{Results}

The median PVL in all HTLV-1-infected carriers was $1.5 \%$ of infected cells (IQR, interquartile range 0.12$5.3 \%$ ), $60 \%$ of them had PVL higher than $1 \%$ of infected cells. There were no statistically significant differences in markers of cellular activation of $\mathrm{CD} 4^{+} \mathrm{T}$-lymphocytes between PVL $\geq 1 \%$ and $<1 \%$ HTLV-1-infected groups (Figure 1A). The proportion of both $\mathrm{CD} 44^{+} \mathrm{CD} 25^{+}$ $\mathrm{CD}_{45 \mathrm{RO}^{+}}$and $\mathrm{CD} 4+\mathrm{HLA}^{-\mathrm{DR}^{+}}{ }^{+}$-cells from infected individuals with $\mathrm{PVL} \geq 1 \%$ was higher than healthy donors $(13.2 \%$ vs $4.0 \%, \mathrm{p}=0.02 ; 18.0 \%$ vs. $8.3 \%, \mathrm{p}=0.02$, respectively).

Moreover, the frequency of $\mathrm{CD}^{+} \mathrm{CD} 25^{+} \mathrm{CD} 45 \mathrm{RO}^{+} \mathrm{T}$ cell subset was directly correlated to the HTLV-1 PVL $(\mathrm{R}=0.7, \mathrm{p}=0.003)$.

Concerning the $\mathrm{CD}^{+} \mathrm{T}$-cell subset (Figure 1B), the frequency of $\mathrm{CD}^{+} \mathrm{CD} 28^{+}$cells was similar between $\mathrm{PLV} \geq 1 \%$ and $<1 \%$ groups. A lower frequency of cells expressing CD28 was observed in HTLV-1-infected individuals with $\mathrm{PVL}<1 \%$ (median $64 \%$, IQR $51-75 \%$ ) compared to healthy donors (median 91\%, IQR 71-98\%) $(\mathrm{p}=0.01)$.

A higher frequency of $\mathrm{CD} 4^{+} \mathrm{IFN}-\gamma^{+} \mathrm{T}$-cells $(4.5 \%)$ was observed in the $\mathrm{PVL} \geq 1 \%$ group, compared to healthy donors $(1 \%)(\mathrm{P}=0.01)$, while frequencies of $\mathrm{CD}^{+} \mathrm{IFN}-\gamma^{+}$ T-cells was similar for HTLV-1 infected groups and healthy donors (Figure 2). The frequencies of individuals with spontaneous lymphocyte proliferation in the group PVL $\geq 1 \%$ (72\%, 13 out of 18$)$ was similar to that observed in the group $\mathrm{PVL}<1 \%(64 \%, 7$ out of 11$)(\mathrm{P}=0.69)$. There was no difference between the magnitudes of proliferation between both groups. However, considering only patients that presented spontaneous proliferation, a positive correlation between PVL and magnitude proliferation was observed $(\mathrm{R}=0.7 ; \mathrm{P}=0.007)$. The frequency of $\mathrm{CD}^{+}{ }^{+} \mathrm{FoxP}^{+}{ }^{+} \mathrm{T}$-cells was higher among individuals infected with HTLV-1, compared to healthy donors $(\mathrm{P}=0.01)$ (Figure 3).

\section{Discussion}

The present study demonstrated that the HTLV-1 PVL is directly associated with immune system activation in asymptomatic carriers. A higher frequency of activated $\mathrm{CD} 4^{+}$T-lymphocytes expressing CD25 + CD45RO+,

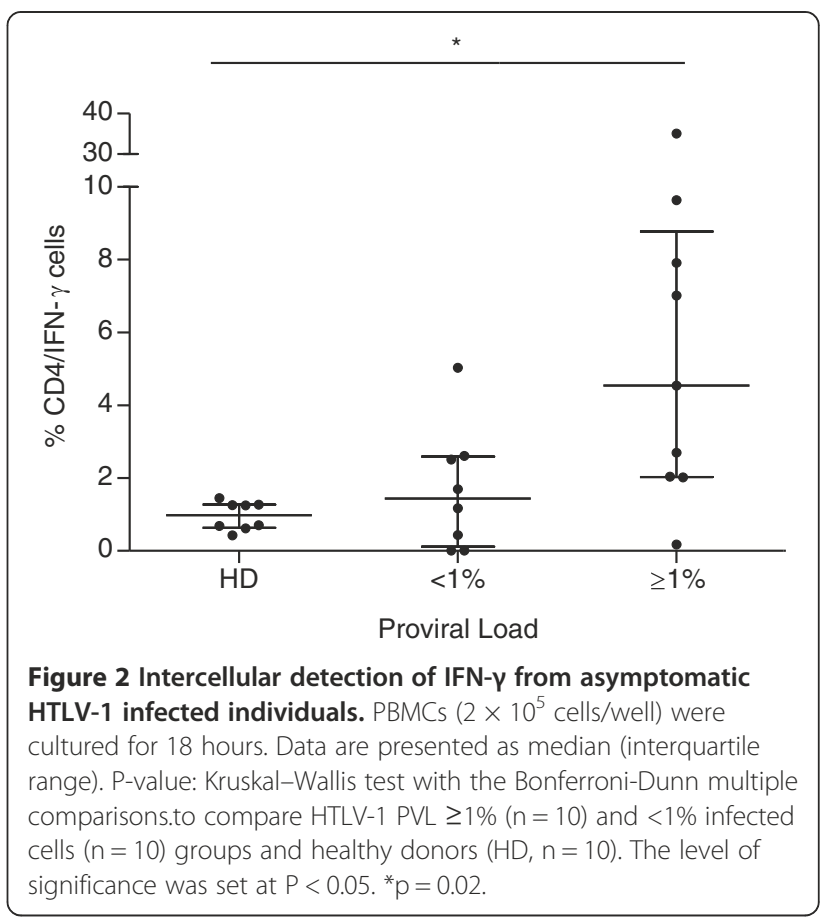

HLA-DR ${ }^{+}$and of cells producing IFN- $\gamma$ were mostly observed in the subgroup of infected individuals with $\mathrm{PVL} \geq$ $1 \%$ of infected cells, compared to healthy donors. A cutoff value of $1 \%$ for PVL was chosen to distinguish between low and elevated levels in accordance with the literature review by Golçalves et al. [20], which considered $<1 \%$ as low, between $1-5 \%$ as intermediate and $>5 \%$ as high. $\mathrm{Al}-$ though the median PVL was determined to be $1.5 \%$, a highly variable percentage of infected cells was observed in included individuals (interquartile range of 0.12-5.3\%). When the cut-off of 1.5 was selected, no significant

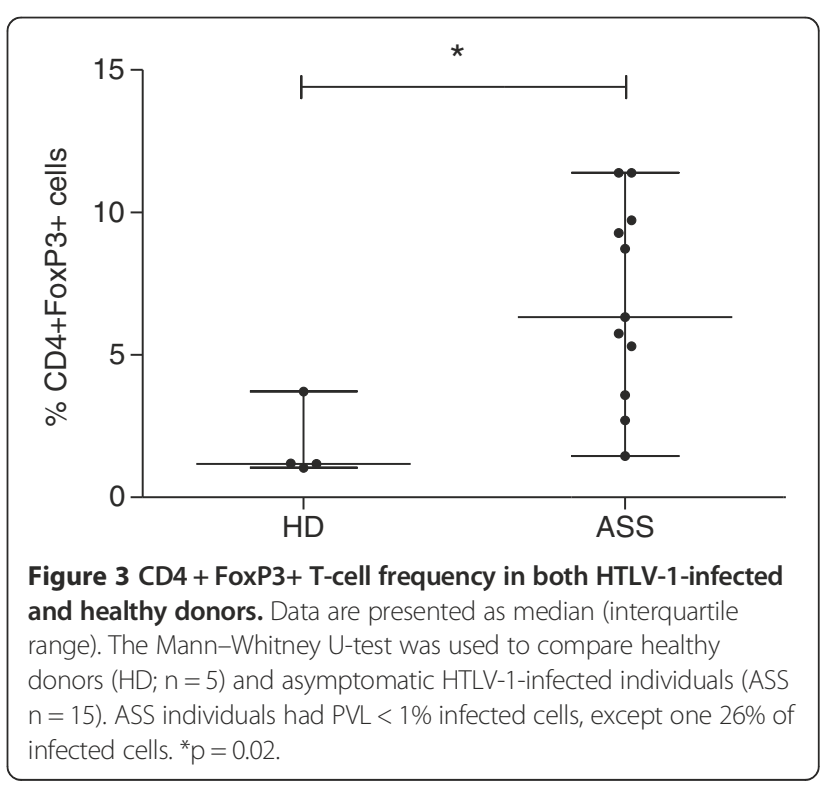


differences were detected in the results presented herein. As such, the 1\% PVL cut-off value was chosen as a representative value.

Activation of T-lymphocytes has been reported more often in HAM/TSP patients. In those, an expansion in the number of $\mathrm{CD}^{+}$and $\mathrm{CD} 8^{+} \mathrm{T}$-lymphocyte subpopulations that present an higher expression of activation molecules such as CD25 and HLA-DR, a decrease in the expression of CD28 costimulatory molecule, compared to asymptomatic carriers $[15,26]$. An exacerbated production of proinflammatory cytokines, such as IL-2, TNF- $\alpha$, IFN- $\gamma$, IL-6, and IL-15 have also been reported more frequently in patients with HAM/TSP [14,27-29]. However, in some asymptomatic HTLV-1-infected individuals the activation of the immune system is similar to those with HAM/TSP $[14,28]$. The influence of HTLV-1 PVL on the immune system was not addressed in these studies.

HTLV-1 PVL represents the number or percentage of host cells harboring a viral copy integrated into a host DNA genome. In the last few years, numerous studies have demonstrated a clear association between high PVL and development of HAM/TSP and of other inflammatory conditions such as infective dermatitis and keratoconjunctivitis sicca. Patients with these conditions have a PVL consistently higher than asymptomatic carriers $[22,24,30]$. Recently, our group suggested a cutoff of $5 \%$ infected cells as best the value to differentiate HAM/ TSP patients from asymptomatic individuals. However, it was observed that about one third of asymptomatic individuals have PVL that exceed this this level [22].

Furthermore, the majority of infected individuals in this study presented spontaneous PBMC lymphoproliferation which was directly correlated with the PVL. Classically, the highest frequency and magnitude of proliferation are found in HAM/TSP [31,32] although a lower frequency of infected asymptomatic individuals also presents similar levels of proliferation [13,14].

The memory $\mathrm{CD}^{+} \mathrm{CD}_{45 \mathrm{RO}^{+}} \mathrm{T}$-cells are the main target for HTLV-1 infection and are preferentially involved in the spontaneous proliferation. It is estimated that the rate of proliferation of memory T-cells induced by the virus reach $3 \%$ per day [33].

The immune response is partially effective maintaining PVL stable over time, probably due to the cytotoxic response mediated by $\mathrm{CD}^{+} \mathrm{T}$-lymphocytes that destroys infected cells. However, the immune response is unable to clear the infection [33-35]. Regarding the subpopulation of $\mathrm{CD} 8^{+} \mathrm{T}$ cells, our study showed a reduced expression of CD28 in the HTLV-1-infected group, although statistically significant only in the subgroup with PVL $<1 \%$ compared to healthy donors.

Low expression of CD28 on CD8 ${ }^{+}$T-subset has been described primarily in patients with HAM/TSP [36].
Conversely, in other chronic or persistent infections such as schistosomiasis, Chagas' disease, and HIV infection a decrease of CD28 expression is also found [35,37,38].

CD28 is a costimulatory molecule expressed on T lymphocytes that interacts with natural ligands CD80 and CD86 located on antigen-presenting cells that result in cell activation. The reduction on CD28 expression found herein may represent a deactivation pathway of the immune system.

On the other hand, a fivefold increase in the frequency of regulatory $\mathrm{T}$ cells $\left(\mathrm{CD} 4^{+} \mathrm{FoxP}^{+}\right)$was observed in the group infected with HTLV-1, compared to healthy donors. These results were similar to those obtained by other studies $[17,39]$ indicating that the virus drives an expansion of regulatory T-cells. This expansion however would not be sufficient to control cell activation induced by the HTLV-1 infection. However, it has been reported that Forkhead box P3 (FOXP3) protein may be transiently expressed on activated $\mathrm{T} \mathrm{CD} 4^{+}$cells and its expression does not necessarily convey regulatory function $[40,41]$. In the present study, we were unable to evaluate the function of these cells.

\section{Conclusions}

In summary, the results presented herein indicate that intermediate HTLV-1 PVL is associated with activation of both $\mathrm{CD}_{4}^{+}$and $\mathrm{CD} 8^{+} \mathrm{T}$-lymphocytes in asymptomatic individuals. Prospective studies should be conducted to evaluate whether asymptomatic individuals with higher PVL and high immune activation are more prone to developing HTLV-1-associated diseases. The HTLV-1 PVL may be a relevant marker in monitoring asymptomatic individuals.

\section{Competing interests}

There is no conflicting financial interest.

\section{Authors' contributions}

$\mathrm{RC}$, study design, performed experiments, data collection and data analysis, first author. MFRG, study design, project leader, 1nd senior author. ABK, performed experiments, data collection and data analysis, co-author. VNO, performed experiments, data collection and data analysis, co-author. BGC, manuscript completion, 2st senior author. REM, study design, data collection and data analysis, co-ordination of manuscript review by co-authors. All authors read and approved the final manuscript.

\section{Acknowledgments}

This study was supported by the Fundação de Amparo à Pesquisa da Bahia (FAPESB). We thank Dr. Raymond Césarie for providing HTLV/Albumina clones and M. Andris K. Walter for his assistance in English revision.

Received: 19 March 2014 Accepted: 18 August 2014

Published: 22 August 2014

\section{References}

1. Poiesz BJ, Ruscetti FW, Gazdar AF, Bunn PA, Minna JD, Gallo RC: Detection and isolation of type $C$ retrovirus particles from fresh and cultured lymphocytes of a patient with cutaneous T-cell lymphoma. Proc Natl Acad Sci USA 1980, 77(12):7415-7419.

2. Gessain A, Cassar O: Epidemiological aspects and world distribution of HTLV-1 infection. Front Microbio/ 2012, 3:388. 
3. Gessain A, Barin F, Vernant JC, Gout O, Maurs L, Calender A, de The G: Antibodies to human T-lymphotropic virus type-I in patients with tropical spastic paraparesis. Lancet 1985, 2(8452):407-410.

4. Osame M, Usuku K, Izumo S, ljichi N, Amitani H, lgata A, Matsumoto M, Tara M: HTLV-I associated myelopathy, a new clinical entity. Lancet 1986 1(8488):1031-1032.

5. Yoshida M, Miyoshi I, Hinuma Y: Isolation and characterization of retrovirus from cell lines of human adult T-cell leukemia and its implication in the disease. Proc Natl Acad Sci USA 1982, 79(6):2031-2035.

6. Mochizuki M, Yamaguchi K, Takatsuki K, Watanabe T, Mori S, Tajima K: HTLV-I and uveitis. Lancet 1992, 339(8801):1110.

7. LaGrenade L, Hanchard B, Fletcher V, Cranston B, Blattner W: Infective dermatitis of Jamaican children: a marker for HTLV-I infection. Lancet 1990, 336(8727):1345-1347.

8. Nakada K, Kohakura M, Komoda H, Hinuma Y: High incidence of HTLV antibody in carriers of Strongyloides stercoralis. Lancet 1984, 1(8377):633.

9. Marinho J, Galvao-Castro B, Rodrigues LC, Barreto ML: Increased risk of tuberculosis with human T-lymphotropic virus-1 infection: a case-control study. J Acquir Immune Defic Syndr 2005, 40(5):625-628.

10. Bastos M d L, Santos SB, Souza A, Finkmoore B, Bispo O, Barreto T, Cardoso I, Bispo I, Bastos F, Pereira D, Riley L, Carvalho EM: Influence of HTLV-1 on the clinical, microbiologic and immunologic presentation of tuberculosis. BMC Infect Dis 2012, 12:199.

11. Norris PJ, Hirschkorn DF, DeVita DA, Lee TH, Murphy EL: Human T cell leukemia virus type 1 infection drives spontaneous proliferation of natural killer cells. Virulence 2010, 1(1):19-28.

12. Prince HE, York J, Owen SM, Lal RB: Spontaneous proliferation of memory (CD45RO+) and naive (CD45RO-) subsets of CD4 cells and CD8 cells in human T lymphotropic virus (HTLV) infection: distinctive patterns for HTLV-I versus HTLV-II. Clin Exp Immunol 1995, 102(2):256-261.

13. Mascarenhas RE, Brodskyn C, Barbosa G, Clarencio J, Andrade-Filho AS, Fiqueiroa F, Galvao-Castro B, Grassi F: Peripheral blood mononuclear cells from individuals infected with human T-cell lymphotropic virus type 1 have a reduced capacity to respond to recall antigens. Clin Vaccine Immunol 2006, 13(5):547-552.

14. Santos SB, Porto AF, Muniz AL, de Jesus AR, Magalhaes E, Melo A, Dutra WO, Gollob KJ, Carvalho EM: Exacerbated inflammatory cellular immune response characteristics of HAM/TSP is observed in a large proportion of HTLV-I asymptomatic carriers. BMC Infect Dis 2004, 4:7.

15. Brito-Melo GE, Martins-Filho OA, Carneiro-Proietti AB, Catalan-Soares B, Ribas JG, Thorum GW, Barbosa-Stancioli EF, Grupo Interdisciplinar de Pesquisas Em H: Phenotypic study of peripheral blood leucocytes in HTLV-I-infected individuals from Minas Gerais, Brazil. Scand J Immunol 2002, 55(6):621-628

16. Toulza F, Heaps A, Tanaka Y, Taylor GP, Bangham CR: High frequency of CD4 + FoxP3+ cells in HTLV-1 infection: inverse correlation with HTLV-1-specific CTL response. Blood 2008, 111(10):5047-5053.

17. Yamano Y, Takenouchi N, Li HC, Tomaru U, Yao K, Grant CW, Maric DA, Jacobson S: Virus-induced dysfunction of CD4 + CD25+ T cells in patients with HTLV-I-associated neuroimmunological disease. J Clin Invest 2005, 115(5):1361-1368

18. Ho DD, Neumann AU, Perelson AS, Chen W, Leonard JM, Markowitz M: Rapid turnover of plasma virions and CD4 lymphocytes in HIV-1 infection. Nature 1995, 373(6510):123-126.

19. Sauce D, Larsen M, Fastenackels S, Pauchard M, Ait-Mohand H, Schneider L, Guihot A, Boufassa F, Zaunders J, Iguertsira M, Bailey M, Gorochov G, Duvivier C, Carcelain G, Kelleher AD, Simon A, Meyer L, Costagliola D, Deeks SG, Lambotte O, Autran B, Hunt PW, Katlama C: HIV disease progression despite suppression of viral replication is associated with exhaustion of lymphopoiesis. Blood 2011, 117(19):5142-5151.

20. Goncalves DU, Proietti FA, Barbosa-Stancioli EF, Martins ML, Ribas JG, Martins-Filho OA, Teixeira-Carvalho A, Peruhype-Magalhaes $\mathrm{V}$, Carneiro-Proietti AB: HTLV-1-associated myelopathy/tropical spastic paraparesis (HAM/TSP) inflammatory network. Inflamm Allergy Drug Targets 2008, 7(2):98-107.

21. Olindo S, Lezin A, Cabre P, Merle H, Saint-Vil M, Edimonana Kaptue M, Signate A, Cesaire R, Smadja D: HTLV-1 proviral load in peripheral blood mononuclear cells quantified in $100 \mathrm{HAM} / \mathrm{TSP}$ patients: a marker of disease progression. J Neuro/ Sci 2005, 237(1-2):53-59.

22. Grassi MF, Olavarria VN, Kruschewsky Rde A, Mascarenhas RE, Dourado I, Correia LC, de Castro-Costa CM, Galvao-Castro B: Human T cell lymphotropic virus type 1 (HTLV-1) proviral load of HTLV-associated myelopathy/tropical spastic paraparesis (HAM/TSP) patients according to new diagnostic criteria of HAM/TSP. J Med Virol 2011, 83(7):1269-1274.

23. Primo JR, Brites C, Oliveira Mde F, Moreno-Carvalho O, Machado M, Bittencourt AL: Infective dermatitis and human T cell lymphotropic virus type 1-associated myelopathy/tropical spastic paraparesis in childhood and adolescence. Clin Infect Dis 2005, 41(4):535-541.

24. Castro-Lima Vargens C, Grassi MF, Boa-Sorte N, Rathsam-Pinheiro RH, Olavarria VN, de Almeida Kruschewsky R, Galvao-Castro B: Keratoconjunctivitis sicca of human T cell lymphotropic virus type 1 (HTLV-1) infected individuals is associated with high levels of HTLV-1 proviral load. J Clin Virol 2011, 52(3):177-180.

25. Dehee A, Cesaire R, Desire N, Lezin A, Bourdonne O, Bera O, Plumelle Y, Smadja D, Nicolas JC: Quantitation of HTLV-I proviral load by a TaqMan real-time PCR assay. J Virol Methods 2002, 102(1-2):37-51.

26. Popovic M, Flomenberg N, Volkman DJ, Mann D, Fauci AS, Dupont B, Gallo RC: Alteration of T-cell functions by infection with HTLV-I or HTLV-II. Science 1984, 226(4673):459-462.

27. Azimi $\mathrm{N}$, Jacobson S, Leist T, Waldmann TA: Involvement of IL-15 in the pathogenesis of human T lymphotropic virus type I-associated myelopathy/tropical spastic paraparesis: implications for therapy with a monoclonal antibody directed to the IL-2/15R beta receptor. J Immunol 1999, 163(7):4064-4072.

28. Carvalho EM, Bacellar O, Porto AF, Braga S, Galvao-Castro B, Neva F: Cytokine profile and immunomodulation in asymptomatic human T-lymphotropic virus type 1-infected blood donors. J Acquir Immune Defic Syndr 2001, 27(1):1-6.

29. Nishiura Y, Nakamura T, Ichinose K, Shirabe S, Tsujino A, Goto H, Furuya T, Nagataki S: Increased production of inflammatory cytokines in cultured CD4+ cells from patients with HTLV-I-associated myelopathy. Tohoku J Exp Med 1996, 179(4):227-233.

30. Primo J, Siqueira I, Nascimento MC, Oliveira MF, Farre L, Carvalho EM, Bittencourt AL: High HTLV-1 proviral load, a marker for HTLV-1 associated myelopathy/tropical spastic paraparesis, is also detected in patients with infective dermatitis associated with HTLV-1. Braz J Med Biol Res 2009, 42(8):761-764.

31. Itoyama Y, Minato S, Kira J, Goto I, Sato H, Okochi K, Yamamoto N: Spontaneous proliferation of peripheral blood lymphocytes increased in patients with HTLV-I-associated myelopathy. Neurology 1988, 38(8):1302-1307

32. Matsumoto $M$, Sugimoto $M$, Nakashima H, Imamura F, Kawano O, Uyama $E$, Takatsu K, Araki S: Spontaneous T cell proliferation and release of soluble interleukin-2 receptors in patients with HTLV-I-associated myelopathy. Am J Trop Med Hyg 1990, 42(4):365-373.

33. Asquith B, Zhang Y, Mosley AJ, de Lara CM, Wallace DL, Worth A, Kaftantzi L, Meekings K, Griffin GE, Tanaka Y, Tough DF, Beverley PC, Taylor GP, Macallan DC, Bangham CR: In vivo T lymphocyte dynamics in humans and the impact of human T-lymphotropic virus 1 infection. Proc Natl Acad Sci USA 2007, 104(19):8035-8040.

34. Hanon E, Hall S, Taylor GP, Saito M, Davis R, Tanaka Y, Usuku K, Osame M, Weber JN, Bangham CR: Abundant tax protein expression in CD4+ T cells infected with human T-cell lymphotropic virus type I (HTLV-I) is prevented by cytotoxic T lymphocytes. Blood 2000, 95(4):1386-1392.

35. Caruso A, Cantalamessa A, Licenziati S, Peroni L, Prati E, Martinelli F, Canaris AD, Folghera S, Gorla R, Balsari A, Cattaneo R, Turano A: Expression of CD28 on CD8+ and CD4+ lymphocytes during HIV infection. Scand J Immunol 1994, 40(5):485-490.

36. Brito-Melo GE, Souza JG, Barbosa-Stancioli EF, Carneiro-Proietti AB, Catalan-Soares B, Ribas JG, Thorum GW, Rocha RD, Martins-Filho OA, Grupo Interdisciplinar de Pesquisas em H: Establishing phenotypic features associated with morbidity in human T-cell lymphotropic virus type 1 infection. Clin Diagn Lab Immunol 2004, 11(6):1105-1110.

37. Dutra WO, Martins-Filho OA, Cancado JR, Pinto-Dias JC, Brener Z, Gazzinelli G, Carvalho JF, Colley DG: Chagasic patients lack CD28 expression on many of their circulating $\mathrm{T}$ lymphocytes. Scand $J$ Immunol 1996, 43(1):88-93.

38. Martins-Filho OA, Cunha-Melo JR, Lambertucci JR, Silveira AM, Colley DG, Gazzinelli G, Correa-Oliveira R: Clinical forms of human Schistosoma mansoni infection are associated with differential activation of T-cell subsets and costimulatory molecules. Dig Dis Sci 1999, 44(3):570-577. 
39. Satou Y, Utsunomiya A, Tanabe J, Nakagawa M, Nosaka K, Matsuoka M: HTLV-1 modulates the frequency and phenotype of FoxP3 + CD4+ T cells in virus-infected individuals. Retrovirology 2012, 9:46.

40. Allan SE, Crome SQ, Crellin NK, Passerini L, Steiner TS, Bacchetta R, Roncarolo MG, Levings MK: Activation-induced FOXP3 in human T effector cells does not suppress proliferation or cytokine production. Int Immunol 2007, 19(4):345-354.

41. Kmieciak M, Gowda M, Graham L, Godder K, Bear HD, Marincola FM, Manjili MH: Human T cells express CD25 and Foxp3 upon activation and exhibit effector/memory phenotypes without any regulatory/suppressor function. J Trans/ Med 2009, 7:89.

doi:10.1186/1471-2334-14-453

Cite this article as: Coutinho et al: Human T lymphotropic virus type 1 (HTLV-1) proviral load induces activation of T-lymphocytes in asymptomatic carriers. BMC Infectious Diseases 2014 14:453.

\section{Submit your next manuscript to BioMed Central and take full advantage of:}

- Convenient online submission

- Thorough peer review

- No space constraints or color figure charges

- Immediate publication on acceptance

- Inclusion in PubMed, CAS, Scopus and Google Scholar

- Research which is freely available for redistribution 